\title{
PERFORMATIVITAS GENDER DAN SEKSUALITAS DALAM WEBLOG LESBIAN DI INDONESIA
}

\author{
Ari Setyorini \\ FKIP Universitas Muhammadiyah Surabaya \\ Email: arisetyorini@gmail.com
}

\begin{abstract}
This study is aimed to know how gender and sexuality are performed in weblogs belonging to Indonesian lesbians. This research is particularly purposed to identify the ideological meaning behind the performative identity of lesbian bloggers, and also to measure hir resistance against subordination. This is a multidis-ciplinary-based qualitative research using Foucault's concepts of power relations and technology of the self (as elaborated in History of Sexuality) and Butler's theory of performativity. This study then applies Fairclough's analytical method of Critical Discourse Analysis (CDA). This research takes Fried Durian, an Indonesian lesbian weblog, as its corpus.

The result of the research confirms that the identification of lesbian identity tends to be the combination of femininity and masculinity. Through the process of crisscrossing, a lesbian performs hirself by doing "stage performativity", embedding the identification of feminine and masculine identity through hir appearance, clothing, gesture, and sexuality. Thus, a lesbian blogger is a creative producer in which zie transforms the heteronormative discourse.
\end{abstract}

Keywords: Weblog, Lesbian, Gender, Sexuality, Performativity

\begin{abstract}
ABSTRAK
Kajian ini bertujuan untuk mengetahui bagaimana identitas gender dan seksualitas ditampilkan dalam weblog lesbian Indonesia. Melalui tampilan tersebut, penelitian ini bertujuan mengetahui makna ideologis dibalik tampilan identitas gender dan seksualitas blogger lesbian Indonesia, serta sejauh mana praktik resistensi atas subordinasi terhadap lesbian ditampilkan dalam weblog. Kajian ini merupakan kanjian multidisiplin menggunakan pemikiran Foucault tentang relasi-kuasa, teknologi diri yang terangkum dalam History of Sexuality, serta pemikiran Butler mengenai perfomativitas. Selanjutnya, kajian ini menggunakan Critical Discouse Analysis (CDA) sebagai metode analisis. Sebagai kospus, kajian ini mengambil satu weblog lebian Indonesia, Fried Durian.

Hasil penelitian mengkonfirmasikan bahwa identifikasi gender dan seksualitas lesbian yang cenderung merupakan kombinasi terhadap femininitas dan maskulinitas. Melalui proses criss-crossing lesbian memperformativitaskan diri mereka dengan "aksi panggung", menempelkan identifikasi identitas feminin dan maskulin melalui dandanan, pakaian, gesture tubuh, dan seksualitas. Senyatanya, blogger merupakan produser kreatif atas wacana lesbian di mana mereka mereproduksi wacana heteronormativitas, hingga wacana tersebut tidak menjadi satu-satunya wacana dominan
\end{abstract}

Kata Kunci: Weblog, Lesbian, Gender, Seksualitas, Performativitas 


\section{PENGANTAR}

Pesatnya perkembangan teknologi dan informasi yang melahirkan internet dirayakan banyak orang. Internet mampu membentuk sistem komunikasi global yang mengubah hubungan personal menjadi sebuah ekspresi disclosed intimacy (Woodward dalam Jordan dan Phil, 2002), di mana seseorang dapat merasa dekat dengan orang lain tanpa harus menghadirkan dimensi ketubuhan mereka. Hubungan personal tersebut dibangun dalam interaksi performativitas tanpa menghadirkan tubuh. Dengan kata lain, komunikasi hadir melalui tulisan, suara, gambar, video dalam layar komputer, dalam dunia virtual. Sehingga, identitas pengguna dalam dunia nyata dapat ditinggalkan, seperti ungkapan Howard Rheingold (1994), people in virtual communities do just about everything people do in real life, but we leave our bodies behind. Identitas hanyalah berdasar pada apa yang pengguna tampilkan. Seseorang dapat menjadi siapa saja dan apa saja sesuai dengan apa yang mereka inginkan. Bahkan pengguna memiliki pilihan anonimitas untuk menutupi identitas dirinya dari pengguna lain. Maka tak heran jika kemudian ada ungkapan yang mengatakan: on the internet, no one knows if you are a dog.

Selama ini kelompok termarjinalkan, utamanya LGBT (Lesbian, Gay, Biseksual, dan Transeksual) belum mendapat tempat sebagaimana kelompok heteroseksual. Di Indonesia sendiri, heteronormativitas menjadi ideologi dominan yang dilanggengkan oleh regime of truth yang berkuasa, misalnya oleh negara, agama, kedokteran bahkan oleh keluarga. Hal ini tampak dari beberapa aksi menentang eksistensi LGBT yang muncul dari berbagai kalangan. Misalnya, aksi demo terhadap ILGA yang berujung diberhentikannya kegiatan yang semestinya diadakan di Surabaya Maret 2010.

Media pun tak luput dari perpanjangan tangan rejim kebenaran untuk membentuk stereotip LGBT. Isu-isu LGBT dan homoseksualitas akhirnya dianggap kebanyakan orang sebagai sesuatu yang negatif dan terlarang. Mohamad Yasir Alimi (2004) dalam bukunya, Dekonstruksi Seksualitas Poskolonial: dari Wacana Bahasa hingga Wacana Agama, menyimpulkan bahwa heteronormativitas masih menjadi wacana dominan yang dikonstruksi oleh media mainstream (Alimi mengambil Kompas sebagai media mainstream yang dikaji).

Akibatnya, banyak individu LGBT yang harus menutupi identitas mereka dalam dunia nyata. Karenanya, kehadiran cyberspace dengan kecairan sifatnya dianggap mampu menjadi media alternatif untuk menyuarakan ketertindasan LGBT dalam menunjukkan identitas mereka, atau sebagai media untuk coming out of the closet. Selain itu pergeseran posisi subyek dalam kacamata posmodernitas, di mana subyek-subyek kecil mulai memiliki suara untuk menentang struktur kuasa, memungkinkan lesbian Indonesia sebagai subyek kecil untuk dapat berbicara, mengungkap identitas gender dan seksualitas mereka.

Berangkat dari pendapat Bryson (2004) bahwa masih sedikit penelitian yang mengkaji tentang komunitas perempuan marjinal, utamanya perempuan lesbian, biseksual dan transeksual dalam kaitannya dengan cyberspace, maka tulisan ini akan mengkaji mengenai hal tersebut. Tulisan ini difokuskan pada performativitas blogger lesbian Indonesia dalam mengkonstruksikan identitas gender dan seksualitas mereka melalui blog. Blog dipilih sebagai media obyek kajian dengan alasan bahwa media ini memiliki kelebihan dari bentuk cyberspace lainnya. Di antaranya adalah karateristiknya sebagai jurnal online pribadi yang mengutamakan personalitas dan individualitas pemiliknya. Individualitas inilah yang melahirkan ekspektasi terhadap blog sebagai media alternatif.

Williams (Mitra dan Gajjala, 2008) mengatakan bahwa blog dianggap mampu menjadi ruang yang memungkinkan lahirnya resistensi-resistensi atas struktur kuasa yang ada melalui cara speaking back. Cara ini mungkin dilakukan ketika blogger menampilkan subyektivitas sebagai individu yang menyuarakan keterasingan dan keter- 
tindasan dari tindakan opresif stuktur berkuasa. Singkatnya, Williams menilai blog sebagai media yang memuat individualization ideologies. Sejalan dengan pemikiran tersebut, David Gauntlett (2002: 65) juga menjelaskan mengenai kemampuan new media (khususnya website pribadi dan web$\log$ ) menyediakan alternatif-alternatif lain bagi individu atau grup sebagai tandingan atas ide dominan tentang perempuan dan laki-laki.

Kajian ini akan mengupas mengenai perfomativitas identitas yang tampak pada weblog lesbian di Indonesia. Kemudian, kajian ini akan menggunakan teori Michel Foucault mengenai sejarah seksualitas dan relasi kuasa akan digunakan untuk mempertajam analisa. Lebih lanjut, kajian ini menggunakan teori identitas ala Judith Butler, di mana identitas dianggap sebagai sebuah performansi. Mengingat bahwa permasalah performativitas bukan hanya mengenai bagaimana seseorang atau sesuatu ditampilkan, namun juga mengenai apa maksud yang melatar belakangi penampilan tersebut, maka lebih detail penelitian ini akan menjawab permasalahan mengenai: (1) bagaimana identitas gender dan seksualitas lesbian ditampilkan dalam blog tersebut; dan (2) bagaimana praktik resistensi terhadap wacana dominan mengenai identitas gender dan seksualitas tampak dalam blog tersebut.

\section{PEMBAHASAN \\ Konsep Identitas sebagai Performativitas}

Kajian ini menempatkan diri dalam perspektif posmodernis. Dalam hubungannya dengan identitas gender dan seksualitas, posmodernis mulai menanyakan mengenai konsepsi kedua identitas tersebut terhadap para pemikir sebelumnya. Menurut posmodernis, feminisme kedua kontinum tersebut telah gagal memahami identitas seksualitas perempuan. Rubin (Alimi, 2004: 8-9) berpendapat, feminisme (kontinum sebelum posmodern) terlalu banyak terkonsentrasi pada gender dan menyepelekan seksualitas.
Kalaupun ada perbincangan soal seksualitas, feminisme kontinum sebelum posmodern masih an sich membicarakannya dalam bingkai heteroseksualitas. Meskipun sukses dalam menjelaskan ketidakadilan sosial berbasis gender, feminisme gagal memberikan penjelasan atas ketidakadilan yang terjadi karena orientasi seksual. Karenanya, kemudian muncul apa yang disebut sebagai queer, yang menjadi pokok pemikiran gender dan seksualitas periode posmodern ini.

Queer, secara seksualitas, diartikan juga sebagai konseptualisasi atas non-heteroseksual, khususnya seksualitas same-sex. Jagose, lebih lanjut, menjelaskan bahwa dalam pandangan queer, apa yang disebut sebagai gender dan seksualitas adalah identitas tidak stabil dan inkoheren (Jagose, 1996: 73-79). Queer, menyitir pendapat Eve Sedgwick (Beasley, 2005: 108), dideskripsikan sebagai criss-crossing terhadap garis-garis identifikasi (self identity) dan hasrat (seksualitas) di antara gender, seksualitas dan identitas lainnya. Dengan kata lain, queer berkonsentrasi pada mixing up traditional assumption regarding supposedly inevitable combintion of attributes of the self. Misalnya, seseorang dengan gender feminin dapat saja mengombinasikan identitasnya sebagai maskulin yang tertarik pada gender feminin lain, yang secara seks dan seksualitas adalah sebagai perempuan. Kombinasi ini dipahami sebagai lesbian. Sejalan dengan pemikiran tersebut, Judith Butler (1993: 116-117) menjelaskan bahwa queer dapat digunakan sebagai strategi alternatif bagi resistensi, misalnya oleh lesbian.

Sebagaimana yang telah disinggung di atas, feminisme posmodern mempertanyakan heteronormativitas atas identitas seksualitas serta gender differences yang ada dalam tubuh perempuan. Pemikiran ini merupakan kontribusi signifikan dari Michel Foucault, yang tertuang dalam bukunya The History of Sexuality I: Will to Knowledge (1998). Pemikiran Foucault mengenai seksualitas bertolak belakang dari pemikiran seksualitas konservatif yang bertumpu pada determinisme biologis. Ini ke- 
mudian menjadi ide dasar feminisme posmodern dalam memahami diskursus gender dan seksualitas. Dia menggugat diskursus yang dibangun oleh regime of truth, seperti psikolog, dokter, maupun gereja yang menganggap esensialisme seksualitas sebagai sebuah realitas alamiah yang berada di luar sejarah, asosial dan tidak berubah.

Seksualitas tidak dipahami sebagai semacam natural yang terberi yang oleh kekuasaan dicoba untuk dikendalikan, atau sebagai domain gelap yang oleh kekuasaan dicoba untuk disingkap sedikit demi sedikit. Seksualitas adalah nama yang diberikan pada sebuah konstruksi sejarah bukan realitas tersembunyi yang susah untuk dipahami, tetapi merupakan sebuah jaringan luas yang tampak jelas dimana stimulasi atas tubuh, intensifikasi kenikmatan, pembentukan terhadap diskursus, pembentukan pengetahuan tertentu, penguatan terhadap kontrol dan resistensi, dikaitkan antara satu dengan yang lainnya (Foucault, 1998: 105106) Pendeknya, seksualitas dalam kacamata Foucault dideskripsikan dalam relasi antara pleasure-power-knowledge.

Pemikiran Foucault ini, kemudian dikembangkan lebih lanjut oleh Judith (1990) Butler dalam bukunya Gender Trouble: Feminism and the Subversion of Identity. Sex, bagi Butler dipahami bukan hanya sebagai sebagai fenomena biologis, melainkan sebuah kostruk ideal yang dimaterialkan oleh waktu dengan cara memaksa dan terus-menerus melalui norma-norma pengaturan. Sehingga, di dalam sex terdapat regulatory practice yang mendisiplinkan tubuh. Jika Foucault menempatkan seksualitas sebagai sesuatu yang terkonstruksi, maka Butler menarik konsep ini lebih jauh dalam termaterialisasikannya seksualitas dalam tubuh, the materiality of sex. Tubuh tidak hanya dipahami sebagai plat yang di atasnya kemudian dibentuk seksualitas dan gender, namun gender dan seksualitas itu sendiri yang dimateriilkan menjadi tubuh.

Telah dijelaskan pada poin sebelumnya konsep Foucault mengenai teknologi diri, bahwa praktik ethics memungkinkan diri melakukan performativitas. Konsep ini dikembangkan lebih jauh oleh Butler, utamanya dalam kaitannya dengan identitas gender. Menurut dia, identitas dibentuk secara performatif melalui diskursus. Identitas gender merupakan efek yang diproduksi oleh individu karena menampilkan praktik-praktik, Butler menyebutnya sebagai gender act, yang secara sosial disepakati sebagai penanda identitas sebagai perempuan atau laki-laki.

Butler (1990: 136) menggambarkan bagaimana realness atau kebenaran tentang gender dan seksualitas diproduksi dan direproduksi melalui serangkaian tindakan, gestur dan hasrat yang mengimplikasikan identitas gender paling essensial. Waria, obyek yang dikaji oleh Butler, harus melakukan serangkaian pratik dan prosedural tertentu untuk memperoleh bentuk yang diidealkan di mana gesture dan penampilan mereka dianggap feminin. Praktik ini bagi mereka, menurut Butler, tidak sekadar menirukan femininitas perempuan. Lebih jauh, mereka juga menunjukkan bahwa femininitas adalah sebuah praktik peniruan, baik itu ketika dilakukan oleh waria maupun perempuan. Singkatnya, penentu the effect of realness adalah kemampuan untuk menghasilkan naturalised effect (Butler, 1993: 129).

Dengan demikian, ditegaskan bahwa waria bukan sedang meniru yang asli, melainkan menginspirasikan bahwa yang asli itu tidak ada, yang ada hanyalah layers of performances hingga membentuk efek yang benar-benar dianggap alamiah. Praktik yang demikian juga sekaligus memparodikan anggapan-anggapan tradisional mengenai apa yang disebut feminitas dan maskulinitas. Bahwa penis tidak harus berperan maskulin, dan vagina juga tidak harus feminin "... the notion of an original or primary gender identity is ... parodied within the cultural practices of drag, cross-dressing, and the sexual stylisation of butch/ femme identities ..." (Butler, 1999: 174). Tidak ada identitas gender di balik ekspresi gender, karena gender adalah sebuah proses imitasi, pengulangan dan performativtas yang tidak pernah ber- 
henti. Identitas gender, karenanya, bukanlah sebuah hal yang tetap.

Melalui proses imitasi pula, heteroseksulitas dinaturalkan dengan proses yang berulang-ulang. Ia beroperasi melalui devaluasi, stigmatisasi dan abnormalitas praktik seksual lainnya. Melalui konsep Foucault, histerisasi tubuh perempuan, Butler kemudian menegaskan bahwa gender dan seksualitas saling berkaitan dan saling berkelitkelindan satu sama lain. Secara bersamasama, gender dan seksualitas berinteraksi untuk menentukan definisi maskulinitas dan feminitas, dan juga membentuk relasi gender dengan menetapkan kondisi di mana orang dengan beragam gender berinteraksi. Kecenderungan orang akan membentuk hubungan heteroseksual terletak pada konstruksi sosial praktek dan kategori gender yang hirarkis dan dikotomis (Butler, 1999: 17)

Korpus penelitian kajian ini adalah weblog lesbian di Indonesia. Tulisan ini akan menampilkan satu blog milik sepasang partner lesbian, Lushka dan Mithya. Weblog mereka berjudul Fried Durian (selanjutnya disingkat FD). Weblog ini dipilh bedasarkan jumlah pengunjung yang cukup tinggi serta keajegan mereka dalam melakukan posting.

\section{Memaknai Identitas Gender dan Seksualitas dalam Fried Durian}

FD adalah weblog milik sepasang partner bernama virtual Lushka (L) dan Mitya (M). Struktur weblog ini terdiri dari tiga bagian. Bagian pertama berisi judul weblog, yakni Fried Durian, dan deskripsi terhadap identitas weblog. Bagian kedua merupakan struktur utama blog memuat post. Post terdiri dari waktu post, judul post, isi post, nama blogger yang melakukan posting, komentar dari pembaca weblog, dan identifikasi topik pembicaraan.

\section{Perbincangan Mengenai Identifikasi Lesbian}

Weblog ini menarik karena dari awal L$\mathrm{M}$ tidak menempatkan identitas mereka ke dalam kategorisasi identitas gender dan seksualitas manapun, baik dalam kategori identitas lesbian, maupun dalam kategori identitas normatif lain. Identifikasi identitas L$M$ pada FD ini pertama kali tampak pada deskripsi yang terletak di bawah judul weblog mereka, yakni: Bisexual is an overstatement. Lesbian is an understatement. We just know how to enjoy live by being in each other arms. This is our fun queer story from Indonesia. Melalui deskripsi ini, L-M mendeskripsikan queer-itas identitas mereka. Perbandingan identitas yang tampak dalam pemilihan kata overstatement (sebagai biseksual) dan understatement (sebagai lesbian) menunjukkan bahwa kategorisasi identitas tersebut tidak cukup mewakili mereka. Bagi L-M, penyebutan sebagai biseksual sebagai identitas mereka merupakan sesuatu yang berlebihan.

Sementara, identifikasi sebagai lesbian, bagi L-M, terlalu menyimplifikasi dan kurang cukup mewakili kompleksitas identitas mereka. Di sinilah tampak bagaimana identitas gender dan seksualitas merupakan sebuah hal yang tidak cukup hanya dibatasi melalui kategorisasi-kategorisasi tertentu, pun bukan pula sebagai sesuatu yang stabil dan koheren. Inkoherenitas tampak pada identifikasi L-M terhadap gender dan seksualitas yang bukan sebagai biseksual maupun lesbian (homoseksual), juga bukan sebagai heteroseksual. L-M bahkan dengan gamblang menyebut identitas mereka sebagai queer, di mana gender dan seksualitas bagi mereka adalah sebuah instabilitas. Identitas menjadi sebuah hal yang tidak ajeg, karena L-M menempatkan identitas sebagai sebuah hal yang dapat diubah, sebagai sebuah proses criss-crossing (Segwick dalam Beasley, 2005: 108).

Deskripsi tersebut diperjelas melalui beberapa post L-M dalam FD. M mendeskripsikan identifikasi dirinya,

“...gue nggak suka memasukkan diri gue ke kategori mana pun... dalam dunia kategori lesbian (femme, butch, andro)...Gue lebih suka mengelaborasi atau menggambarkan perilaku daripada menamai. Yep, saat ini gue in a rela- 
tionship dan bahkan jatuh cinta dengan Lushka. Tapi saying myself a lesbian? Lah, I'm not that in to women juga. Masih bisa ngiler liat cowok berbadan atletis dan berwajah lutcu... " (Mithya, 2008, "Don't Label Yourself", <http//www.frieddurian.blogspot.com> diakses Senin, 8 Desember 2008).

M tidak melakukan kategorisasi dirinya berdasar identitas gender yang telah ada. Penggunaan istilah 'mengelaborasi (identitas)' mendeskripsikan tindakan untuk memperlakukan identitas sebagai sebuah hal yang dapat diubah atau diuraikan -pendeknya berada dalam sebuah proses, ketimbang sebuah hasil ajeg dalam kategorisasi. M memilih untuk tidak mengkategorisasikan dirinya menjadi femme, butch atau andro, karena kategorisasi lesbian tersebut tidak cukup mewakili dirinya. M menampilkan diri sebagai lesbian melalui partnership yang dilakukannya dengan L. Akan tetapi, M mengakui bahwa dirinya juga memiliki ketertarikan pada laki-laki (secara bodily sex). Namun, hal tersebut tidak menjadikan M termasuk dalam kategori biseksual. M mengungkapkan, "...soul gue itu sebenernya dilahirkan sebagai cowok biseksual. Jadi untuk jatuh cinta dengan cewek itu normal tapi diem-diem dan takut-takut sangat tertarik dengan cowok lain (especially gay man)." (Mithya, "FilmTwilight +ChauvinisMithya" $<$ http/ / wwww.frieddurian. blogspot.com> diakses Senin, 7 Desember 2008).

Bodily sex $\mathrm{M}$ adalah sebagai seorang perempuan. Namun, $M$ menilai dirinya secara gender adalah laki-laki yang memiliki ketertarikan seksual pada perempuan (secara bodily sex dan gender), sekaligus kepada lakilaki (secara bodily sex) yang feminin (gay man). M menilai jika ketertarikannya dengan perempuan adalah sebuah hal yang 'normal', sebagaimana normativitas laki-laki tertarik kepada perempuan. Lebih lanjut, ketertarikan $\mathrm{M}$ pada laki-laki dinilainya sebagai sebuah hal 'kesalahan', karena M menilai dirinya adalah laki-laki pula. Karenanya, M menilai, ketertarikannya dengan lakilaki dilakukan secara diam-diam dan takuttakut. Bahkan secara spesifik dalam kutipan sebelumnya, M menjelaskan bahwa ia tertarik dengan laki-laki yang 'bertubuh atletis' dan 'berwajah lucu.'

Kombinasi tubuh atletis dan berwajah lucu menjadi hal yang menarik, karena pada dasarnya kedua deskripsi tersebut menunjukkan hal yang saling bertentangan. Tubuh atletis kerap diidentikan dengan kejantanan atau maskulinitas laki-laki. Sebaliknya, diksi 'lucu' acap kali diasosiasikan dengan sesuatu yang tidak maskulin -feminin. Berwajah lucu dapat diartikan sebagai berwajah polos, lugu, dan menggemaskan. Di sini ditunjukkan bagaimana identitas dan atribut diri diotak-atik sedemikian rupa. Maskulin dikombinasikan dengan feminin, homoseksual dipadu-padankan dengan heteroseksual. Hingga pada akhirnya, tidak ada yang disebut sebagai identitas utama dalam diri M. M tidak bisa dikategorikan sebagai lesbian (homoseksual) seutuhnya, bukan termasuk sebagai heteroseksual. M melakukan kombinasi-kombinasi terhadap identitas-identitas gender dan seksual.

Melalui FD, L juga menggambarkan identitas dirinya sebagai 'lesbian yang bersyarat'. Maksudnya adalah partnership yang dijalaninya dengan $\mathrm{M}$ merupakan partnership lesbian. Tetapi, sebagaimana $\mathrm{M}$, dirinya juga memiliki kemungkinan untuk tertarik secara seksual terhadap laki-laki. Ditegaskan oleh L, "Gue dan Mithya ga ngeklaim diri kita murni lesbian tapi juga ga menolak kenyataan kalau saat ini gue berdua dalam hubungan sesama jenis" (Lushka, "Tobat Jadi Lesbian?" http://www.narth.com> diakses Selasa, 14 Juli 2009).

Deskripsi-deskripsi identitas tersebut menunjukkan ambiguitas dan hibriditas LM dalam memaknai dirinya. Namun, hal ini tidak kemudian menjadi sebuah hal negatif karena ambiguitas tersebut menurut Butler (1993: 29) justru merupakan sebuah strategi untuk menggoyang apa yang disebut sebagai identitas center-margin. Normativitas masyarakat menganggap identitas yang koheren adalah identitas center, identitas yang paling benar. Artinya, seseorang akan dianggap benar jika identitas gender yang 
mereka tampilkan sesuai dengan bodily sex dan hasrat seksualitas mereka. Dengan kata lain, jika individu memiliki bodily sex sebagai perempuan, maka gender mereka harus menunjukkan femininitas dan tertarik secara seksual kepada laki-laki. Namun, yang dilakukan L-M ini justru mensubjetivikasi identitas tersebut dan menunjukkan bahwa apa yang disebut sebagai gender dan seksualitas hanyalah persoalan bagaimana hal tersebut diperformansikan. Hal ini akan nampak pada perilaku-perilaku dalam menampilkan identitas-identitas mereka yang dibahas dalam sub-sub bab selanjutnya.

Pernyataan L-M untuk tidak mengkategorisasikan dirinya, senyatanya juga merupakan sebuah bentuk kategori lain, yakni no label. No Label menjadi sedikit banyak mewakili apa yang dijelaskan L-M ketika memilih untuk tidak memasukkan diri mereka ke dalam kategori lesbian sebagai femme, butch, dan andro. Sebagaimana pemikiran queer bahwa a refusal of a set identity adalah identitas itu sendiri. (Ibid.) Melalui no label, L-M mensubversi identitas yang telah ajeg dengan melakukan serangkaian percampuran terhadap normativitas identitas gender dan hasrat akan seksualitas sebagaimana ide Butler atas gender trouble.

\section{Performativitas Penampilan dan Fisik}

Dunia cyber adalah dunia yang tidak membutuhkan hadirnya tubuh. Artinya, tubuh secara artifisial tidak harus dihadirkan untuk mewakili identifikasi identitas diri. Dimensi tubuh dapat dihadirkan melalui kata-kata, suara dan gambar. Karenanya, identifikasi fisik L-M dalam FD ini tampak melalui kata-kata dalam post. Penolakan L$M$ untuk tidak mengategorikan dirinya ke dalam femme-butch-andro mempengaruhi cara bagaimana mereka menampilkan identitas gender dan seksualitas melalui tampilan fisik. Mereka cenderung mengkombinasikan penanda-penanda gender yang tampak melalui penampilan tubuh. Misalnya ketika L menceritakan tentang kebiasaan-kebiasaan L-M yang berhubungan dengan pe- nampilan dan atribut fisik: "Siapa bilang kita se-tomboy or se-andro gitu. Emang penampakan gue lebih cewek dari Mithya, tapi kalau buat urusan kerapian Mithya ratunya." (Lushka, "Mithya and Me" < http// www.frieddurian.blogspot.com> diakses Rabu, 10 Maret 2009).

Agaknya, banyak yang mengira L-M berpenampilan 'kelaki-lakian'. Hal ini tampak dari pertanyaan retoris L terhadap penampilannya yang cenderung diasumsikan banyak orang sebagai penampilan tomboy. Tomboy, sebagaimana dijelaskan oleh Boelstroff, adalah memiliki sifat "kelaki-lakian" (female-to-male transgenders), yang salah satunya tampak dari penampilan (Boellstroff, 2003). L menolak asumsi tersebut dengan menampilkan gambaran sisi 'keperempuanan' L-M yang tampak dalam kebiasaan mereka terkait penampilan atribut fisik. M memiliki kebiasaan-kebiasaan berdandan yang 'lazim' nya dilakukan oleh perempuan. Digambarkan oleh L, bagaimana kepedulian $M$ terhadap rambutnya:

"Turun dari motor, buka helm, dia akan langsung bilang 'rambutku berantakan ga?' -trus gue jawab 'engga' -dia akan ngerapiin lagi, terus nanya 'berantakan ga?', gue tetep akan bilang 'engga' -dia megang2 rambut terus nanya 'beneran?' -nah, di bagian ini gue udah muter bola mata kalo engga melototin dia, ngunci motor terus ngeloyor dengan rambut gue berantakan. Fact: gimana mau berantakan, tiap mau pasang helm dia ngerapiin rambut, trus dijepit, trus dirapiin lagi helmnya" (Lushka, "Mithya and Me" < http// www.frieddurian.blogspot.com> diakses Rabu, 10 Maret 2009).

Pada post ini, L menjelaskan perbandingan penampilan antara dirinya dengan partnernya, M.. Dalam konteks ini, L menilai $\mathrm{M}$ memiliki sisi femininitas dalam penampilan yang lebih dominan daripada $L$. $\mathrm{M}$ memiliki kecenderungan berperilaku 'keperempuan-perempuanan', yang 'kuatir' dengan penampilan rambutnya. Rambut menjadi penanda penting bagi perempuan dalam normativitas masyarakat. Bahkan ada ungkapan yang menyebutkan bahwa rambut adalah mahkota wanita. Lebih lan- 
jut, L menegaskan bagaimana $\mathrm{M}$ memiliki kegemaran berdandan sebagaimana normativitas perempuan dalam masyarakat. Misalnya, M memiliki 'ritual' menyisir rambut, membersihkan wajah, memakai bedak, menyemprotkan minyak wangi, dan terkadang memakai lip gloss ketika berada di toilet, setelah buang air kecil. $\mathrm{M}$ juga selalu membawa peralatan kosmetik di dalam tasnya. "Isi tas: Mithya, selain ada buku, pulpen, dan kertas pasti ada perlengkapan ceweknya, tissue, kertas minyak, sisir, bedak, kaca, lip gloss, perfume, jepitan rambut." Penyebutan 'perlengkapan cewek' di sini menegaskan bahwa kosmetik memang melulu menjadi penanda bagi gender perempuan.

Kebiasaan-kebiasaan M membuat L tertular untuk ikut-ikut menunjukkan femininitas dirinya melalui tampilan tubuh dengan berdandan. Disebutkan oleh L, "Dulu, gue boro2 di tas ada bedak, sisir aja ada udah ajaib, yang wajib ada di tas itu buku, pulpen, dan notes. Sekarang, gue jadi ketularan Mithya, kemana-mana bawa peralatan ngelenong" (Ibid). L mengumpamakan peralatan kosmetik sebagai peralatan ngelenong (lenong). Hal ini mengindikasikan bahwa, bagi L, berdandan yang melibatkan peralatan kosmetik, tak ubahnya sebagai sebuah aksi pertunjukan lenong. Ketika L menampilkan dirinya yang berdandan menggunakan perlengkapan kosmetik, tak ubahnya seperti ketika pemain-pemain lenong yang akan melakukan pertunjukan. Pada pertunjukan lenong, setiap pemain akan menunjukkan sebuah karakter fiktif yang berbeda dengan karakter mereka sebenarnya. Pada akhirnya, berdandan bagi L adalah untuk menampilkan sebuah karakter fiktif yang berbeda dengan karater dirinya yang sebenarnya.

Menyitir pendapat Butler (1990: 174) bahwa persoalan gender hanya semata persoalan performativitas, proses imitasi dan pengulangan yang tidak pernah berhenti, demikian halnya yang dilakukan oleh L-M. Penampilan fisik yang diidentifikasi oleh masyarakat sebagai identitas gender dijadikan sebagai sarana untuk memperformansi gender mereka sebagaimana normativitas masyarakat. Mereka oleh masyarakat dianggap sebagai perempuan melalui performansi ritual-ritual berdandan.

Hal yang menarik, L-M tak hanya berhenti pada tataran berdandan sebagai penanda identitas perempuan. L-M menggambarkan pertentangan-pertentangan dalam penampilan fisik mereka sebagai bentuk instabilitas gender. Misalnya, ketika L menjelaskan dominansi sisi femininitas dirinya yang tampak dari pilihan-pilihan pakaian, aksesoris dan sepatu. Beda halnya ketika L merasa kurang menyukai berdandan, sehingga sisi maskulinitas dirinya lebih dominan dalam hal berdandan. Sebaliknya, Mithya justru sangat tidak 'perempuan' ketika berurusan dengan busana, sepatu dan aksesoris. L menjelaskan: "Rok untuk dipake harian itu adalah big no no buat Mithya. Paling kalo mau kondangan aja dia baru mau. ... Mithya sekarang baru belajar pake sepatu2 cewek. Untuk harian dia masih setia ama Conversenya" (Lushka, "Mithya and $\mathrm{Me}^{\prime \prime}<$ http//www.frieddurian. blogspot. com> diakses Rabu, 10 Maret 2009).

Pakaian berbentuk rok, bagi masyarakat kita, adalah pakaian bagi perempuan. Karenanya, lazim jika perempuan memakai rok sebagai penanda keperempuanan mereka. Buktinya, seragam sekolah hingga baju bekerja perempuan rat-rata memiliki pakaian bawahan berbentuk rok. Rok pun kemudian identik dengan simbol femininitas. Namun, M menampilkan bentuk lain dari pilihan penggunaan rok sebagai identifikasi gender dirinya. Bagi $\mathrm{M}$, rok bukanlah pakaian sehari-hari yang merepresentasikan dirinya. Ia hanya menggunakan rok jika mengadiri acara resmi, misalnya resepsi pernikahan.

Selanjutnya, dijelaskan pula jika M lebih menyukai menggunakan converse, merk sepatu jenis kasual yang biasanya dikenakan oleh laki-laki. Pada pilihan ini, M menunjukkan sisi maskulinitas dirinya. Maskulinitas $\mathrm{M}$ ditegaskan $\mathrm{L}$ dalam postnya yang lain, "Have I told you that mithya is very handsome" (Lushka, "Mamerin Pacar Ah..." 
<http//www.frieddurian.blogspot. com> diakses Sabtu, 28 November 2008). Penyebutan 'handsome' menjelaskan penampakan $\mathrm{M}$ yang ganteng mirip laki-laki secara fisik. Lebih lanjut, L menjelaskan penampilan M yang maskulin membuat beberapa teman $\mathrm{L}$ mengira $\mathrm{M}$ adalah pacar $\mathrm{L}$, yang tentunya dalam anggapan mereka $\mathrm{M}$ adalah laki-laki.

Penggambaran-penggambaran tersebut menunjukkan non konformitas $\mathrm{M}$ dalam menentukan pilihan-pilihan terhadap tampilan tubuh. Di satu sisi, ritual berdandan $\mathrm{M}$ menandakan gender femininitas dirinya, namun di sisi lain maskulinitas muncul dari pilihan $\mathrm{M}$ akan model pakaian dan sepatu yang cenderung manly. Non konformitas juga ditunjukkan $\mathrm{M}$ saat menjelaskan bahwa soul dirinya terlahir sebagai laki-laki, namun di sisi lain $\mathrm{M}$ juga melakukan ritualritual yang menandakan identitas keperempuannya.

Meski L-M menempatkan diri mereka sebagai a refusal of a set identity atau tak berlabel, namun dari penggambaran penampilan fisik, L-M cenderung menunjukkan penampilan androgini dalam hubungan lesbian. Baik L maupun M melakukan pemilihan terhadap beberapa identitas feminin yang kemudian dikombinasikan dengan identitas maskulin. Pada akhirnya crisscrossing identitas tersebut membentuk identitas lain yang berbeda dari identitas normatif dalam masyarakat, identitas androgini.

Melalui criss-crossing, seperti yang dilakukan oleh L-M, apa yang disebut identitas gender center yang normatif tersebut dipermain-mainkan. Bahwa individu dapat saja melakukan modifikasi dengan menampilkan gender act secara subversif seperti yang dilakukan L-M dalam penampilannya. $\mathrm{M}$ yang memiliki ritual berdandan, akan tetapi kurang menyukai penggunaan rok dan sepatu perempuan. L yang kurang suka memakai kosmetik, namun menyukai rok, sepatu dan aksesoris perempuan. Performansi gender act yang dilakukan oleh LM memang tak selamanya mulus. Terkadang mereka harus menerima 'hukuman' dari orang-orang di sekeliling mereka jika ternyata gender act yang mereka tampilkan tidak sesuai dengan 'lazimnya'. Misalnya ketika $\mathrm{M}$ menceritakan bagaimana dirinya harus menampilkan identitas gender yang selaras dengan penampilan sebagaimana normatif masyarakat. Diceritakan M,

“... gue ...ngga suka dengan acara resepsi
pernikahan. Gue kayak alergi dengan baju-
baju pesta perempuan. Setiap hadir di resepsi
pernikahan gue bakal sesak napas dan mulai
banjir keringat karena canggung. Gue pasti
jadi pusat perhatian. Gimana ngga, Mithya
yang tomboy dan kayak laki itu dateng den-
gan full make up dan dress cantik. ... a lot of
people said that I am beautiful kalo mau
didandanin dan pakai baju feminin. But it's
just not me" (Mithya, "I Hate Wedding Recep-
tion" < http/ / www.frieddurian.blogspot.
com> diakses Senin, 12 Oktober 2009).

$\mathrm{M}$ harus menampilkan pilihan-pilihan gender yang selaras sebagaimana yang dinormatifkan masyarakat jika sedang menghadiri resepsi pernikahan, meski hal tersebut membuat dirinya tidak nyaman. M menceritakan bahwa suatu saat dirinya mencoba berpenampilan tidak seperti yang dinormatifkan masyarakat terhadap gender perempuan ketika menghadiri acara resepsi. Kemudian, ternyata hal tersebut dinilai orang-orang sekitarnya sebagai sebuah hal yang tidak lazim, $M$ 'ditegur' untuk penampilannya tersebut. Pada akhirnya, $\mathrm{M}$ harus 'tunduk' terhadap normativitas masyarakat akan keselerasan penampilan tubuhnya dengan gender: "Akhirnya gue harus menerima norma masyarakat yang satu ini. ... For now Mithya harus dateng ... mengenakan pakaian perempuan lengkap dan dandanan tebal, berusaha menjadi cewek-cewek kebanyakan di sekitarnya" (Ibid). Hal ini sesuai dengan apa yang disebut Foucault sebagai biopower. Masyarakat mengatur norma-norma tertentu untuk mengatur tubuh individu. Tubuh Mithya didisiplinkan melalui norma-norma masyarakat.

M telah membuktikan bahwa, di balik ketundukan $\mathrm{M}$ terhadap keselarasan antara penampilan dan identitas ini, apa yang disebut sebagai gender perempuan hanyalah bentuk-bentuk impersonasi. M meniru tam- 
pilan gender perempuan dengan mengikuti normatif masyarakat akan 'kepantasan', yakni berdandan dan berpakaian perempuan (rok) untuk acara-acara formal seperti resepsi pernikaha, meskipun sebenarnya diri $\mathrm{M}$ merasa tidak sesuai dengan tampilan tersebut. Namun, justru aksi tiru itu, membuat $\mathrm{M}$ dikategorikan sebagai perempuan dan akhirnya diterima oleh masyarakat. Karenanya, tak ada yang dapat disebut sebagai identitas asli, yang ada hanya bentukbentuk impersonasi yang diulang-ulang di bawah tekanan, melalui apa yang disebut sebagai larangan, penyebutan atas tabu (Butler, 1993: 95) atau apa yang dinyatakan sebagai pantas-tidak pantas.

\section{Performativitas Aktivitas Seksual}

Post L-M dalam FD beberapa kali menggambarkan aktivitas seksual mereka sebagai partner lesbian. Seperti misalnya diceritakan oleh M:

\section{"I spread kissess along your lips, neck, then to your breast where I lingered, gently squeezing every each one of them. ... my lips eagerly returned to you back, your neck, and my hand cupped each and one of your breast. ... my hand between your thigh, touching you. Your legs opened for me, and I slip between them, thrusting deeply as I can into you. As I make love to you, your breathing became fran- tic. ... suddenly you screamed out as I touched the right spot, and as I felt the trembling wrack of your body, the pleasure burst through me as well..." (Mithya, "While you sleep..." < http// www.frieddurian.blogspot.com> diakses Ka- mis, 7 Juni 2007)}

Gambaran $M$ tersebut menunjukkan aktivitas seksual mereka, mulai dari foreplay hingga aktivitas utama seks. Yang menarik, M menyebut seks oral sebagai aktivitas utama seks mereka, bukan sebagai foreplay. Hal ini menjadi kritik bagi konstruksi masyarakat yang menyebut aktivitas seksual di luar penetrasi adalah aktivitas seksual tambahan, aktivitas seksual pemanasan. Hal ini tampak dari pilihan kata 'make love' yang biasanya dikaitkan dengan aktivitas seksual penetratif, namun mereka gunakan untuk menggambarkan seks utama mereka, seks oral.
Bandingkan pemakaian diksi 'make love' (have sex) dengan 'make out'. Diksi pertama acap kali diidentikkan dengan seksual penetratif, sementara diksi selanjutnya sering terkait dengan aktivitas seksual non penetratif, salah satunya adalah seks oral (Encarta Dictionary, 2008).

Aktivitas seksual yang ditampilkan oleh L-M menggambarkan bahwa apa yang disebut pleasure dalam aktivitas seksual, sebenarnya tidak terpaku pada bineritas anatomi tubuh, vagina-penis. L-M menunjukkan bahwa pleasure dalam seksualitas dapat terjadi bahkan pada dua anatomi tubuh yang sama, perempuan dengan perempuan, vagina dengan vagina. Salah satu hal terpenting dalam aktivitas seksual, yakni orgasme, dapat terjadi tanpa melibatkan perbedaan anatomi tubuh. Seperti yang dijelaskan $\mathrm{M}$ saat menggambarkan proses orgasme: "...you screamed out as I touched the right spot, and as I felt the trembling wrack of your body, the pleasure burst through me as well" (Ibid). Persoalan seksualitas bagi L-M adalah persoalan ketepatan menemukan spot yang benar, karenanya dapat dilakukan baik itu dengan sesama jenis, maupun berbeda jenis kelamin.

Dipahami bahwa aktivitas seksual yang dianggap benar oleh masyarakat adalah aktivitas seksual prokreasi. Namun, selayaknya partnership lesbian yang lain, seksualitas bagi L-M tidak melulu diartikan sebagai aktivitas melestarikan keturunan karena mustahil bagi mereka untuk memperoleh keturunan secara biologis dari partner mereka. Variasi aktivitas seksual, seperti handjob, seks oral, dan seks di tempat umum, dilakukan oleh L-M lebih karena hasrat seksual itu sendiri.

Apa yang dilakukan L-M dengan melakukan kombinasi terhadap identitas gender-seksualitas dengan tidak menjalankan keduanya sebagaimana normativitas masyarakat, sesuai dengan apa yang disebut Butler (1990: 36-37) sebagai pastiche. L$M$ melakukan perpaduan terhadap identitas gender feminin-maskulin dan seksualitas perempuan dan laki-laki. Melalui cara 
ini L-M melakukan mockering terhadap apa yang disebut sebagai masyarakat sebagai normativitas gender dan seksualitas utama. Seksualitas bagi L-M bukanlah persoalan dikotomisasi anatomi tubuh atau pula perkara halal-haram, tapi lebih pada pleasure itu sendiri.

\section{Blog sebagai Media Resistensi}

Penyebutan L-M mengenai diri mereka yang tak terkategorikan, nyatanya masih juga berpola pada pengelompokan sifat-sifat feminin dan maskulin. Disebutkan oleh L bagaimana sisi feminin $\mathrm{M}$ atau komentar $M$ mengenai tuntutan masyarakat untuk bersifat feminin karena bodily sex mereka adalah perempuan, merupakan bukti bahwa dalam dunia nyata mereka tidak pernah bisa melepaskan kategorisasi feminin dan maskulin. Namun, L-M menyadari benar bahwa dalam dunia online mereka dapat bermain-main dan memanipulasi identitas yang dilekatkan pada mereka. L menjelaskan bahwa dirinya memiliki dua blog, satu blog digunakan untuk menampilkan sosok manipulatif dirinya sebagai straight, sementara FD mereka gunakan untuk mengekpresikan represi atas identitas mereka di dunia nyata.

Blog, bagi FD kemudian menjadi media untuk melakukan coming out. Melalui blog, coming out menjadi sebuah momen liberasi, di mana lesbian mampu membuka dirinya kepada orang lain dengan identitas yang berbeda dari identitas mereka di dunia nyata. Kelebihan blog untuk membebaskan mereka mengatur isi serta apa saja yang dapat ditampilkan pada blog mereka. Praktik ini memberikan keleluasaan pada L-M untuk memoderas. Hal ini memberikan autoritas penuh pada L-M terhadap performansi mereka. Mereka tidak lagi harus kuatir dengan coming out yang biasanya jika di dunia nyata diikuti dengan 'ceramah-ceramah' akan dosa praktik homoseksualitas.

Seperti yang digambarkan oleh L-M: "di blog satu-satunya tempat gue mengobati rasa terkekang gue di dunia nyata." Hal tersebut menggambarkan betapa dalam du- nia nyata, lesbian tidak dapat mengekpresikan identitas mereka karena batas-batas apa yang masyarakat sebut sebagai norma ketimuran, tidak memungkin bagi mereka untuk menyebut diri sebagai lesbian. Sebagaimana yang disebutkan Foucault, bahwa subyek menyadari diri mereka sebagai individual yang terbagi-bagi secara seksual, yang selanjutnya menganalisa perilaku seksual mereka tersebut atas dasar moralitas (Mills, 2003: 87). Blog melepaskan dari justifikasi tersebut dan mampu membangun justifikasi baru terhadap heteronormativitas yang ada dalam masyarakat Indonesia.

L-M mereproduksi identitas diri mereka menjadi dua identitas yang berbeda sesuai dengan space yang mereka hadapi, atau mempresentasikan ilusi untuk memberikan impresi identitas yang benar terhadap audience tertentu jika menyitir pendapat Erving Goffman (Gauntlett, 2002). Identitas ganda yang mereka tampilkan berdasarkan impresi identitas 'benar' yang diharapkan audience, membuat L-M menampilkan identitas illusi dalam dunia off line agar tidak dianggap liyan oleh masyarakat heteroseksual. Sementara, mereka menampilkan identitas lain sebagai lesbian pada dunia online karena anonimitas yang diberikan oleh dunia tersebut membuat mereka leluasa menarasikan diri dengan mereproduksi identitas ilusi di dunia off line dan membentuk identitas baru di dunia anonimitas.

Hal ini sejalan dengan ide Foucault (1990 dan 1986) atas teknologi diri, di mana dijelaskannya bagaimana diri bertindak terhadap praktik ethics, standar yang menjadikan diri sebagai sosok tertentu guna digambarkan kepada khalayak. Narasi diri sebagai lesbian pada weblog ini sebagai teknologi berstrategi yang memungkinkan subyek untuk memilih bagaimana hendak menampilkan diri mereka, berbeda dengan narasi yang diproduksi oleh diskursus heteroseksual. Di sini diketahui bahwa subyek adalah aktif, tidak sebagaimana konsep Althusser mengenai agen yang hanya berperan sebagai wayang yang menerima perannya karena tekanan dari apartus-aparatus. 


\section{SIMPULAN}

Narasi diri pada weblog merupakan sebuah 'pengakuan dosa', sebagaimana diceritakan Foucault dalam History of Sexuality bagaimana gereja memberlakukan pengakuan dosa akan seksualitas individu. Namun, berbeda dengan Foucault yang menilai pengakuan dosa tersebut sebagai sebuah hal negatif, narasi diri pada weblog ini malahan menunjukkan bagaimana agen-agen dapat mentranformasikan identitas gender lesbian sebagai identitas yang berbeda dari anggapan normatif. Berbeda dengan konsep agen Althusser di mana tiap agen seolaholah hanya melakoni perannya sebagai wayang dari aparatus-aparatus ideologi dominan, Foucault melalui teknologi diri dan perfomativitas Butler menyebut agen memiliki kemampuan untuk melakukan 'speaking back' ini sebagai strategi. Agen memiliki kemampuan untuk melakukan tindakan yang dilingkupi dengan pengetahuan.

L-M memiliki kuasa untuk mereproduksi narasi diri mereka melalui 'pengakuan dosa', yang justru melawan anggapan negatif atas diskursus heteroseksual. Melalui FD, L-M sebagai agen tahu dengan benar apa yang mereka lakukan, juga paham benar bagaimana normativitas sosial masyarakat dan aturan main di mana mereka dapat melakukan pengakuan dengan keluar dari kloset di weblog, speaking back terhadap homofobia dengan mereproduksi diskursus normatif.

\section{DAFTAR PUSTAKA}

Alimi, M. Y., 2004, Dekonstruksi Seksualitas Poskolonial: dari Wacana Bangsa hingga Wacana Agama, Yogyakarta: LkiS.

Althusser, L., "Ideology and Ideological State Apparatuses (Notes towards an Investigation)" dalam Kellner, Douglass (ed.), 2006, Media and Cultural Studies, Cornwall: Blackwell Publishing Ltd.

Barker, C., 2008, Cultural Studies: Teori dan Praktik (terjemahan Nur Hadi), Yogyakarta: Kreasi Wacana.
Beasley, C., 2005, Gender \& Sexuality: Chritical Theories, Critical Thinkers, London: Sage Publication.

Butler, J., 1990, Gender Trouble: Feminism and the Subversion of Identity, London dan New York: Routledge.

, 1993, Bodies That Matter, New York: Routledge.

1993, "Critically Queer" dalam GLQ: A Journal of Lesbian and Gay Studies, 1.

Bryson, M., 2004, "When Jill Jack in Queer Women and the Net," Feminist Media Studies, Vol. 4, No. 3, New York: Routledge.

Boellstroff, T., 2003, “Dubbing Culture: Indonesian Gay and Lesbi Subjectivities and Ethnography in Already Globalized World" dalam jurnal American Ethnologist, Vol. 30, No. 2.

Fairclough, N., 1989, Language and Power, London \& New York: Longman.

Foucault, M., 1978, The History of Sexuality: An Intorduction, Voume 1, Terjemahan dari Histoire de la Sexualite. New York: Random House Inc. , 1990, The Use of Pleasure: Volume 2 of the History of Sexuality, New York: Vintage Books.

, 1986, The Care of The Self: Volume 3 of the History of Sexuality, New York: Pantheon Books.

Gauntlett, D., 2002, Media, Gender and Identity, New York: Rountledge.

Jagose, Anamarie, 1996, Queer Theory, Melbourne: Melbourne University Press.

Kadir, Hatib Abdul, 2007, Tangan Kuasa dalam Kelamin, Yogyakarta: Insist Press.

Kellner, D., 1995, Media Culture, New York: Routledge.

Mills, S., 2003, Michel Foucault, London dan New York: Routledge.

Mitra, R. dan Gajjala, R., 2008, “Quuer Blogging in Indian Digital Diasporas: a 
Dialogic Encounter" dalam Journal of Communication Inquiry, Vol.3, No.4, London: Sage Publication.

Rubin, G., 1984, 'Thinking Sex: Notes for a Radical Theory of the Politics of Sexuality' dalam C.Vance (ed.), Pleasure and Danger: Exploring Female Sexuality, Boston: Routledge \& Kegan Paul.

Salih, S., 2002, Judith Butler, London dan New York: Routledge.

Sedgwick, E., “Between Men: English Literature and Male Homosocial Desire," dalam Beasley, Chris. Gender $\mathcal{E}$ Sexuality: Chritical Theories, Critical Thinkers, London: Sage Publication. 2005.
Welhmeier, S., (ed.), 2010, Oxford Advance Learner's Dictionary, $7^{\text {th }}$ Edition, New York: Oxford University Press.

William dalam Mitra, Rahul dan Radhika Gajjala, 2008, “Quuer Blogging in Indian Digital Diasporas: a Dialogic Encounter" dalam Journal of Communication Inquiry, Vol.3, No.4, London: Sage Publication.

\section{Sumber Lain:}

http://www.frieddurian.blogspot.com/ 